\title{
SURGICAL TREATMENT OF METASTATIC DISEASE OF THE VERTEBRAL COLUMN
}

\author{
Miljenko Franić, ${ }^{1,2,5}$, Vide Bilićs ${ }^{3,6}$, Stjepan Dokuzović, ${ }^{1,5}$, Stjepan Ćurić3 \\ Tomislav Čengicic ${ }^{3,5}$ and Krešimir Rotim ${ }^{4,5,6}$
}

\begin{abstract}
${ }^{1}$ Department of Traumatology and Orthopedics, Clinical Department of Surgery, Dubrava University Hospital, Zagreb; ${ }^{2}$ Josip Juraj Strossmayer University of Osijek, School of Medicine, Osijek; ${ }^{3} \mathrm{Clinical}$ Hospital of Traumatology, ${ }^{4} \mathrm{Clinical}$ Department of Neurosurgery, Sestre milosrdnice University Hospital Center;

${ }^{5}$ University of Applied Health Sciences; ${ }^{6}$ University of Zagreb, School of Medicine, Zagreb, Croatia
\end{abstract}

SUMMARY - Spinal metastatic disease is a rather common occurrence and definitely warrants attention and treatment due to the high likelihood of leaving cancer patients severely disabled in their final months of life. Recent developments in the understanding of the behavior of different tumor types, as well as advances in surgical treatment, are allowing for the evolution of treatment algorithms, especially when surgical treatment is to be considered. This paper gives an overview of the decisionmaking process and the array of surgical options currently available.

Key words: Spine - surgery; Spine - pathology; Spinal neoplasms, secondary; Neoplasm metastasis surgery; Palliative care - methods; Algorithms; Decision support techniques

\section{Introduction}

The purpose of this article is to give an overview of the approach to treating spinal column metastases in cancer patients. This is a complex field which requires thorough understanding of all treatment modalities available and decisions must be guided by a rational framework based on a number of parameters.

Spinal metastases are by no means an uncommon phenomenon, as virtually any malignant tumor type has the potential to metastasize to bone, with the spine being the predominant bony site ${ }^{1}$.

Since some form of bony metastasis is almost to be expected in advanced stage malignant disease, it may be discovered through targeted screening using any of a number of diagnostic modalities (CT/PET-CT, MRI, bone scan). However, in case of an unknown pri-

Correspondence to: Miljenko Franić, MD, Department of Traumatology and Orthopedics, Clinical Department of Surgery, Dubrava University Hospital, Av. Gojka Šuška 6, HR-10000 Zagreb, Croatia

E-mail:mfranic@kbd.hr

Received August 16, 2016, accepted September 7, 2016 mary tumor, symptoms from the metastases may be the first signs of any illness. In this case, there are many 'red flags' which have been described to help guide the need for spinal malignancy screening ${ }^{2}$. Although none of these red flags except for prior history of cancer carried much weight as a warning sign, careful use of combinations of red flags can be of benefit (age over 50 , pain not relieved after a month of rest, thoracic pain which is worse at night, unexplained weight loss, generally poor state of health, etc. $)^{2}$.

It must be borne in mind that the goals of treatment of spinal metastases differ from the goals of treating primary tumors considering that treatment is seldom curative. In metastatic cases, surgeons strive to improve the overall quality of life in a patient otherwise undergoing treatment for their primary tumor by decreasing pain, relieving neurological impairment, providing stability, and increasing patient independence ${ }^{1}$.

Non-surgical treatment includes chemotherapy, radiotherapy, hormonal therapy (for example, in breast and prostate tumors), angiography and embolization (in highly vascular metastases, including renal cell, 
Table 1. Harrington's classification and treatment principle system

\begin{tabular}{|l|l|}
\hline Classification & Neurologic symptom and degree of bone destruction \\
Class 1 & Minimal neurology \\
Class 2 & Involvement of bone without collapse or instability and minimal neurology \\
Class 3 & Major neurologic impairment without spinal instability \\
Class 4 & Vertebral collapse and instability, without major neurologic impairment \\
Class 5 & Vertebral collapse and instability with major neurologic impairment \\
\hline Treatment principle & \\
Class 1,2 & Chemotherapy, hormonal therapy, radiotherapy \\
Class 3 & Radiotherapy with corticosteroid treatment \\
Class 4,5 & Surgery \\
\hline
\end{tabular}

Table 2. Revised Tokuhashi scoring system for treatment decision guidance based on expected outcome

\begin{tabular}{|c|c|c|}
\hline Characteristic & Score & \multirow{4}{*}{$\begin{array}{l}\text { Total Score } \\
0-8 \longrightarrow \text { Conservative treatment }\end{array}$} \\
\hline General condition (performance status) & & \\
\hline Poor (PS $10 \sim 40 \%)$ & 0 & \\
\hline Moderate (PS 50 70\%) & 1 & \\
\hline Good (PS $80 \sim 100 \%)$ & 2 & \multirow{4}{*}{$\begin{array}{l}\text { Predicted prognosis } \\
6 \text { months }>\end{array}$} \\
\hline No. of extraspinal bone metastases foci & & \\
\hline$\geq 3$ & 0 & \\
\hline $1 \sim 2$ & $\begin{array}{l}1 \\
2\end{array}$ & \\
\hline No. of metastases in the vertebral body & & \multirow{19}{*}{$\begin{array}{l}\text { Predicted prognosis } \\
1 \text { year } \leq\end{array}$} \\
\hline$\geq 3$ & 0 & \\
\hline 2 & 1 & \\
\hline 0 & 2 & \\
\hline Metastases to the major internal organs & & \\
\hline Unremovable & 0 & \\
\hline Removable & 1 & \\
\hline No metastases & 2 & \\
\hline Primary site of the cancer & & \\
\hline Lung, osteosarcoma, stomach, bladder, esophagus, pancreas & 0 & \\
\hline Liver, gallbladder, unidentified & 1 & \\
\hline Others & 2 & \\
\hline Kidney, uterus & 3 & \\
\hline Rectum & 4 & \\
\hline Thyroid, breast, prostate, carcinoid tumor & 5 & \\
\hline Palsy & & \\
\hline Complete (Frankel A, B) & 0 & \\
\hline Incomplete (Frankel C, D) & 1 & \\
\hline None (Frankel E) & 2 & \\
\hline $\begin{array}{l}\text { Criteria of predicted prognosis: Total Score } \\
\text { (TS) } 0 \sim 8=>6 \text { mo; TS } 9 \sim 11=\leq 6 \mathrm{mo} \text {; TS } 12 \sim 15=\leq 1 \mathrm{yr}\end{array}$ & & \\
\hline
\end{tabular}

thyroid, melanoma, giant cell tumors, and hepatocellular carcinomas), and symptom management. Radiotherapy is often used with or without surgery and must be considered where histopathology of the primary tumor is one of known radiosensitivity (breast, prostate, Wilm's tumor, Ewing's sarcoma, lymphoma, seminoma, multiple myeloma, medulloblastoma, etc.), although even in relatively radioresistant histologies 
(lung, renal, etc.) pain relief may be achievable ${ }^{3}$. Chemotherapy has its role in chemosensitive tumors (lymphomas, Ewing's, Wilm's, rhabdomyosarcoma, teratoma, etc.).

Surgery can also have an important role in cases in which it is deemed feasible. Surgical treatment is, of course, not without its own risks to the patient and benefits of the selected treatment modality must always outweigh the risks to the patient. It has long been held as general consensus that minimal life expectancy of 3 to 6 months is the minimum requirement for considering a major surgery ${ }^{4}$. However, in shorter life expectancies, palliative surgical procedures (kyphoplasty, vertebroplasty, placement of a morphine pump) could be beneficial notwithstanding the morbidity they present $^{5}$. In order to help systematize the decision-making process, several classification scoring systems, as well as treatment algorithms have been developed which take into account parameters such as primary tumor histopathology, severity of impairment, overall wellbeing, and likelihood to receive any benefit from surgery.

Harrington has proposed the treatment algorithm shown in Table 1 solely based on the amount of vertebral destruction and instability ${ }^{6,7}$. Enneking, Tomita, and Weinstein/Boriani/Biagini describe patterns of tumor spread throughout a vertebra ${ }^{8}$. The Tokuhashi scoring system shown in Table 2 is one of the commonly used tools for treatment guidance ${ }^{9,10}$. It takes into account the general state of the patient as evaluated by the Karnofsky performance score (shown in Table 3), the number of local (spinal), extraspinal and visceral metastases, tumor histology, and neurological status according to Frankel (summarized in Table 4). However, the modified Bauer score has been shown to be a simpler system because it considers only the parameters which have been shown to mostly influence prognosis (shown in Table 5) ${ }^{11}$. It is reasonable to consider combining several systems in order to synthesize final decision. For example, by using the Harrington principles, the Spinal Instability Neoplastic Score (SINS) (Table 6), Tomita type ${ }^{12}$, and Tokuhashi score together, one can more confidently determine the best course of action for a given patient.

According to histologic subtypes, tumors can be classified into (1) slow growing (breast, prostate, carcinoid, thyroid), (2) moderately growing (kidney, uterus), and (3) rapidly growing (lung, liver, stomach, esophagus, pancreas, sarcomas, bladder) tumors ${ }^{13}$.

\section{Table 3. Karnofsky performance score}

\begin{tabular}{|l|l|}
\hline $\begin{array}{l}\text { Score } \\
100 \\
90\end{array}$ & $\begin{array}{l}\text { Description } \\
\text { Normal; no complaints; no evidence of disease } \\
\text { Able to carry on normal activity; minor signs } \\
\text { or symptoms of disease } \\
\text { Normal activity with effort; some signs or } \\
\text { synptoms of disease }\end{array}$ \\
70 & $\begin{array}{l}\text { Cares for self; unable to carry on normal } \\
\text { activity or to do active work } \\
\text { Requires occasional assistance, but is able to } \\
\text { care for most of his personal needs }\end{array}$ \\
50 & $\begin{array}{l}\text { Requires considerable assistance and frequent } \\
\text { medical care } \\
\text { Disabled; requires special care and assistance } \\
\text { Severely disabled; hospital admission is }\end{array}$ \\
30 & $\begin{array}{l}\text { indicated although death not imminent } \\
\text { Very sick; hospital admission necessary; active } \\
\text { supportive treatment necessary } \\
\text { Moribund; fatal processes progressing rapidly } \\
\text { Dead }\end{array}$ \\
10 &
\end{tabular}

Table 4. Frankel classification of patients according to initial neurological function

\begin{tabular}{|c|}
\hline A - Absence of motor or sensory function below \\
the level of the lesion
\end{tabular}

\section{Table 5. Modified Bauer score}

\begin{tabular}{|l|}
\hline Score 1 point for each of the following positive \\
prognostic factors: \\
- No visceral metastases \\
- No lung cancer \\
- Primary tumor * breast, kidney, lymphoma, \\
multiple myeloma \\
- One solitary skeletal metastasis \\
\hline Suggestions for treatment \\
- Score 0-1: Supportive care, no surgery \\
- Score 2: Short term palliation, dorsal surgery \\
- Score 3-4: Middle term local control, \\
ventral-dorsal surgery \\
\hline
\end{tabular}


Table 6. The Spinal Instability Neoplastic Score (SINS): a score of 0-6 is considered stable, 7-12 potentially unstable, and 13-18 unstable

\begin{tabular}{|c|c|c|}
\hline \begin{tabular}{|l|} 
SINS \\
component
\end{tabular} & Description & Score \\
\hline \multirow[t]{4}{*}{ Location } & $\begin{array}{l}\text { Junctional (occiput-C2, } \\
\text { C7-T2, T11-L1, L5-S1) }\end{array}$ & 3 \\
\hline & Mobile spine (C3-C6, L2-L4) & 2 \\
\hline & Semi-rigid (T3-T10) & 1 \\
\hline & Rigid (S2-S5) & 0 \\
\hline \multirow[t]{3}{*}{ Pain } & Yes & 3 \\
\hline & $\begin{array}{l}\text { Occasional pain but not } \\
\text { mechanical }\end{array}$ & 1 \\
\hline & Pain-free lesion & 0 \\
\hline \multirow[t]{3}{*}{ Bone lesion } & Lytic & 2 \\
\hline & Mixed (lytic/blastic) & 1 \\
\hline & Blastic & 0 \\
\hline \multirow{3}{*}{$\begin{array}{l}\text { Radiographic } \\
\text { spinal } \\
\text { alignment }\end{array}$} & Subluxation/translation & 4 \\
\hline & Kyphosis/scoliosis & 2 \\
\hline & Normal & 0 \\
\hline \multirow{4}{*}{$\begin{array}{l}\text { Vertebral body } \\
\text { collapse }\end{array}$} & $50 \%$ collapse & 3 \\
\hline & $50 \%$ collapse & 2 \\
\hline & $\begin{array}{l}\text { No collapse with } 50 \% \text { body } \\
\text { involved }\end{array}$ & 1 \\
\hline & None of the above & 0 \\
\hline \multirow{3}{*}{$\begin{array}{l}\text { Posterolateral } \\
\text { involvement } \\
\text { of spinal } \\
\text { elements }\end{array}$} & Bilateral & 3 \\
\hline & Unilateral & 1 \\
\hline & None of the above & 0 \\
\hline
\end{tabular}

Knowing the biological behavior of certain subtypes can give one a general sense of urgency required for the overall workup and treatment duration. In all cases, it is prudent to engage a team of spinal surgeons as soon as possible to optimize outcome when surgical intervention is feasible.

\section{Surgical Techniques}

Before the advent of surgical treatment for metastatic spine disease, the standard treatment options were radiotherapy and corticosteroid application. Surgical treatment for spinal metastases first received confirmation of efficacy by Patchell et al., who were the first to demonstrate in a randomized prospective study that patients that were surgically decompressed clearly showed better results than those undergoing only palliative radiotherapy without decompression ${ }^{14}$. Since then, various criteria have been developed for the selection of patients that would benefit most from surgical treatment ${ }^{9,13}$. The degree of spinal cord compression has been better defined ${ }^{15}$, a framework has been established for considering spinal instability brought about by malignant disease ${ }^{16}$, and most recently, the required extent of treatment has been better defined ${ }^{17}$. Thus, spinal surgery has established its place within the complex, multidisciplinary and palliative approach to patients with spinal metastatic disease. The goals of surgical treatment of spinal metastases are local control of tumor size, pain reduction, maintaining motor function and sphincter control, prevention of deformity, and upgrading the quality of remaining lifetime.

However, before deciding on surgical treatment of spinal metastatic disease, it is imperative to know the histology of the specific tumor and the overall spread of the malignant disease, as these are the most important predictors of survival. Therefore, biopsy should be the first step to surgical treatment. Biopsy can be performed percutaneously by needle in local or general anesthesia and under control of an image intensifier or by computerized tomography (Fig. 1). If the result of such a biopsy should turn out negative for malignant cells and strong suspicion of malignancy remains, then open biopsy should be the next step.

Upon deciding on the need of surgical treatment, it may be necessary to perform preoperative embolization of the tumor in order to reduce intraoperative bleeding. This is especially important for histologic types which are prone to excess bleeding (for example, renal cell or thyroid cancer), as seen in Figure 2.

The spinal surgeon has an array of treatment options that differ in invasiveness and how radical the tumor resection should be ${ }^{17}$. The most radical operation is en bloc resection of a tumor according to the principles of treatment of primary spinal tumors ${ }^{12}$. They are divided into 3 types of radical resections: vertebrectomy, sagittal resection of a vertebra, and total resection of posterior elements ${ }^{8}$. The indication for such a procedure would be a controllable histologic type of tumor, the presence of a metastasis that is technically resectable with a surrounding layer of healthy tissue, the lack of other distant metastases, and a generally good overall state of the patient (Fig. 3). 
The complex anatomy of the surrounding structures and the central placement of neural elements within the spinal canal pose a unique challenge to per- forming radical resections of spinal tumors. That is why it is usually only possible to perform a marginal or intralesional resection, or reduction of the tumor along
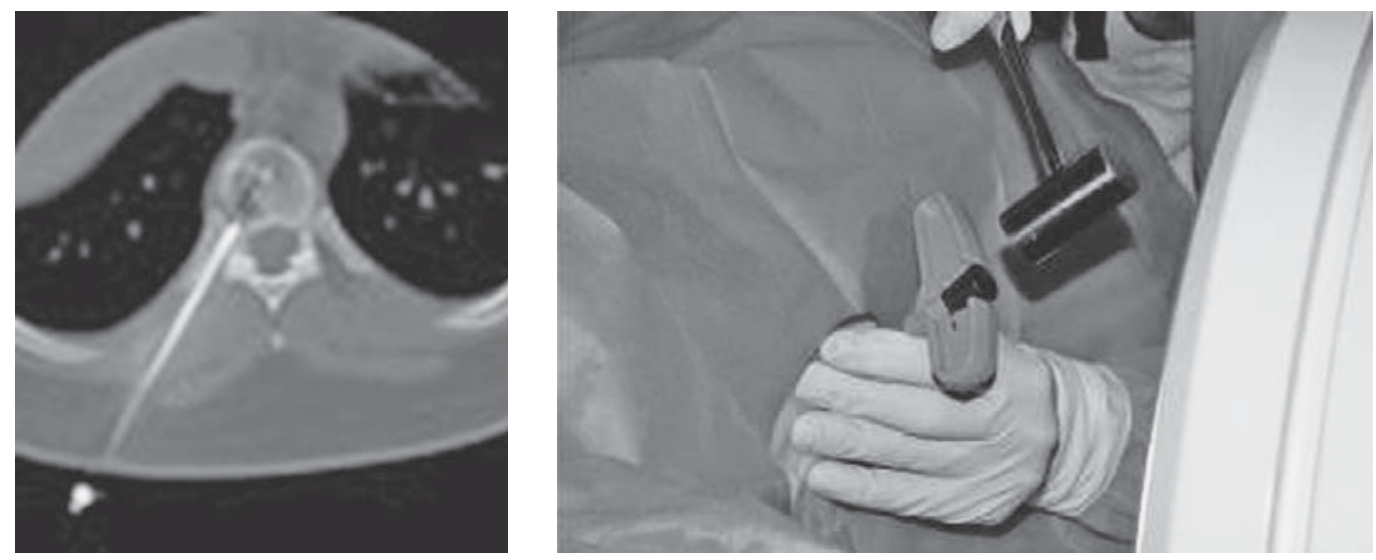

Fig. 1. Computerized tomography guided percutaneous transpedicular placement of a biopsy needle in a thoracic vertebral body.
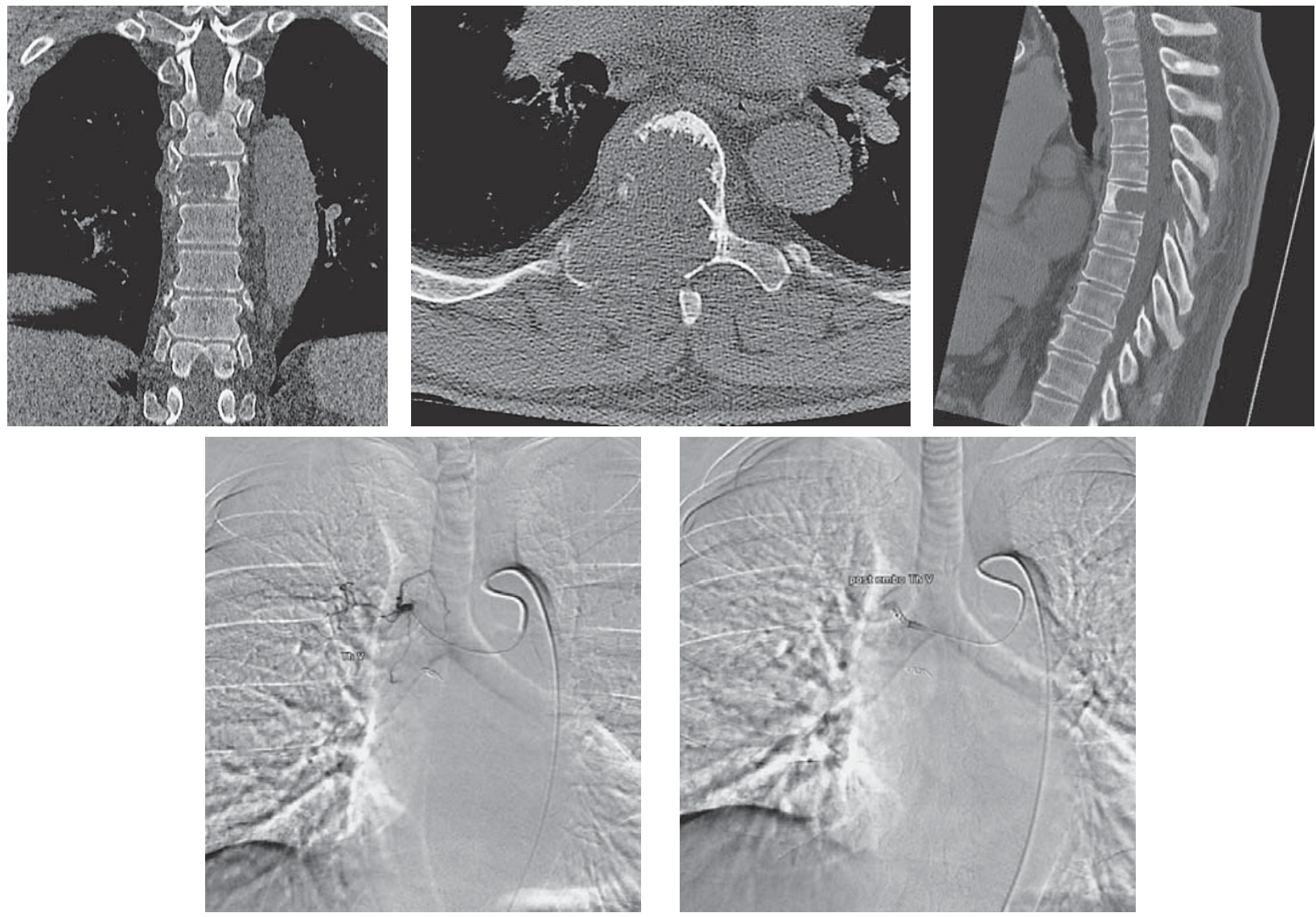

Fig. 2. Computerized tomography images in 3 planes of a highly vascularized thyroid cancer spinal metastasis, followed by pre-and post-embolization fluoroscopy images of the same case. Note the instillation of contrast medium in the pre-embolization image, followed by complete blockage of the feeding vessel in the post-embolization image. 
with stabilization of the spinal column. These procedures are less radical than en bloc resections, although they may yield virtually identical results if stereotactic radiosurgery (which has significantly altered the treatment approach to patients with spinal metastases) is additionally performed ${ }^{19}$.

The goal of modern surgery in metastatic spine disease is to ensure sufficient distancing of the tumor from the spinal cord (separational surgery) and to provide stable fixation of the spinal column to allow for safe application of radiotherapy on the whole tumor volume.

In the case of spinal instability and great pain, which would hinder upright posture and/or ambulation in the patient, there are several ways in which stabilization can be achieved. Stabilization is indicated when there is a clear risk of instability according to the SINS score, re-
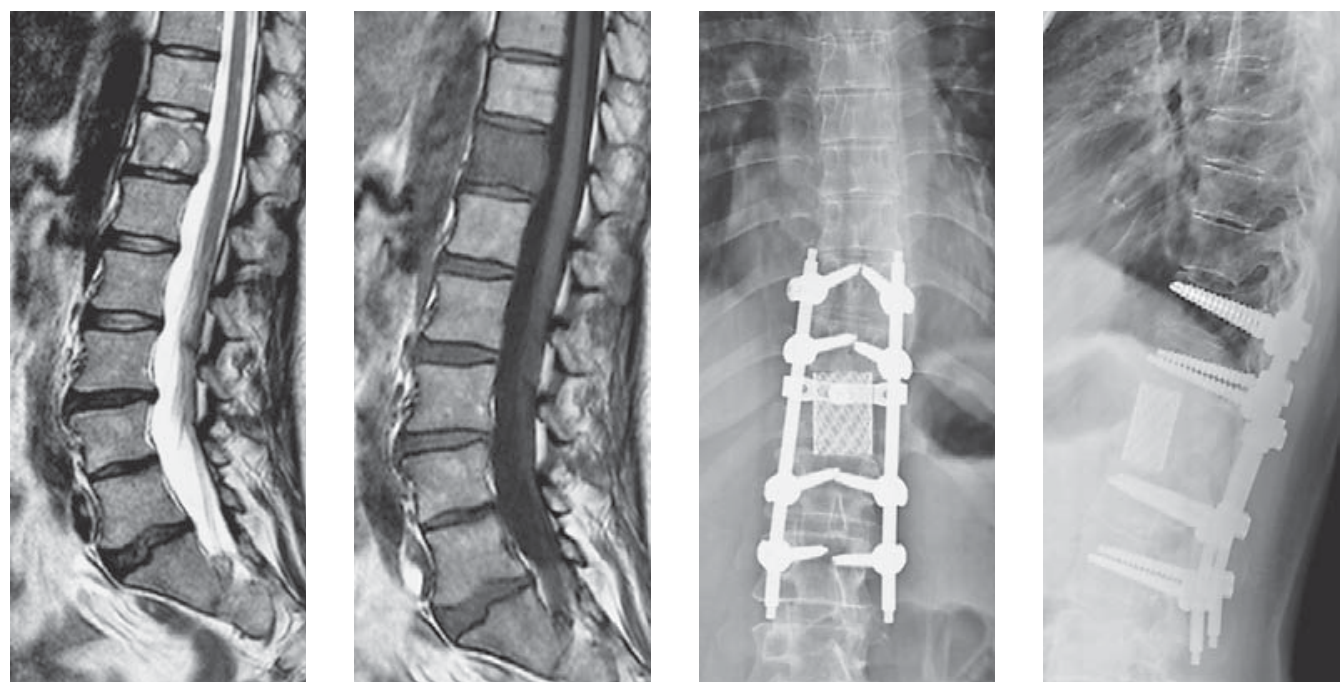

Fig. 3. Magnetic resonance images of a solitary $T h 12$ metastasis of a primary breast cancer, confined to the vertebral body with slight bulging into the epidural space with immediate postoperative plain film radiographs after en bloc vertebrectomy of the above Th12 metastasis with anterior support with a graft-filled mesh cage and posterior transpedicular fixation.
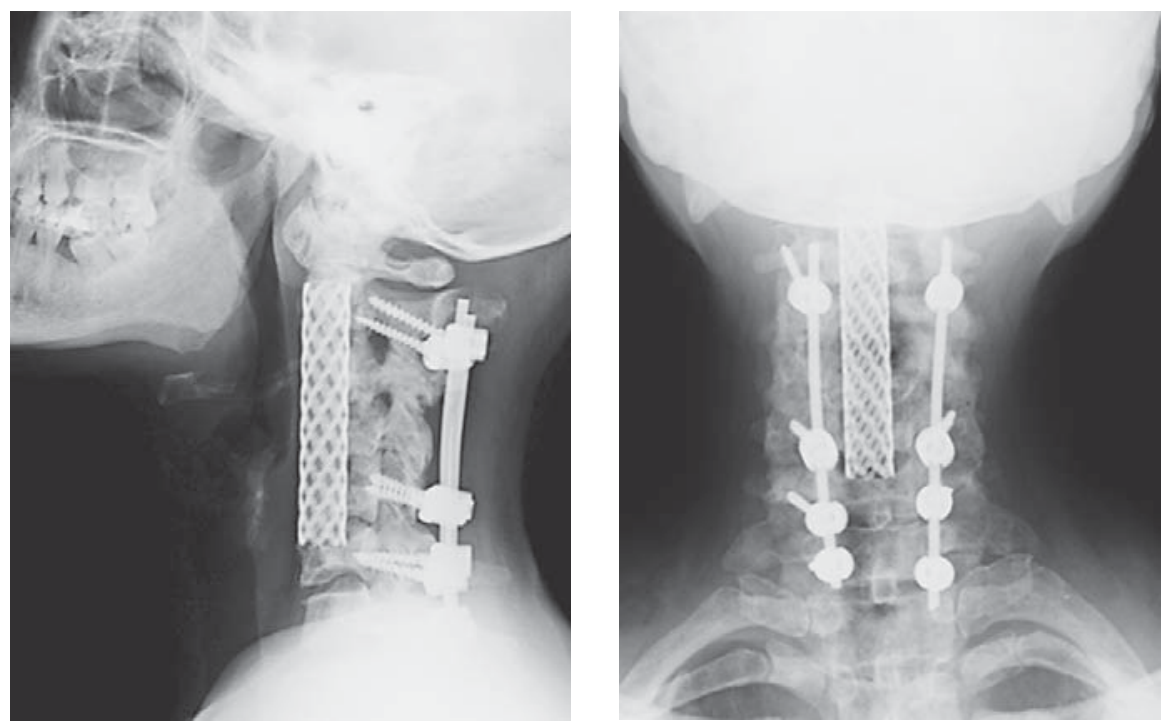

Fig. 4. Plain film radiographic demonstration of typical examples of combined anterior and posterior stabilization using interbody cages filled with graft material anteriorly and lateral mass screws and rods, as in the above cervical segments. 
gardless of histologic tumor type and overall predicted survival, provided that the general state of the patient allows for surgery to be performed, some examples of which can be seen in Figure $4^{14}$. Stabilization methods include open anterior and posterior stabilization, percutaneous stabilization methods, and vertebroplasty or kyphoplasty ${ }^{20}$. Minimally invasive methods for stabilization of the vertebral body are particularly convenient as palliative techniques for patients who otherwise would not be candidates for radical surgery, such as patients with multilevel involvement (Fig. 5) ${ }^{21}$. Percutane- ous stabilization of the spine is indicated in patients in whom there is clear instability without significant spinal cord compression (Fig. 6) ${ }^{22}$.

In the case that the expected remaining lifespan of the patient is under 3 months and there are multiple metastatic changes along the spinal column and unbearable pain that is unresponsive to high doses of opioid analgesics, it is recommended to install an intrathecal opioid pump to be able to control pain with much lower doses of opioids and fewer complications (Fig. 7).
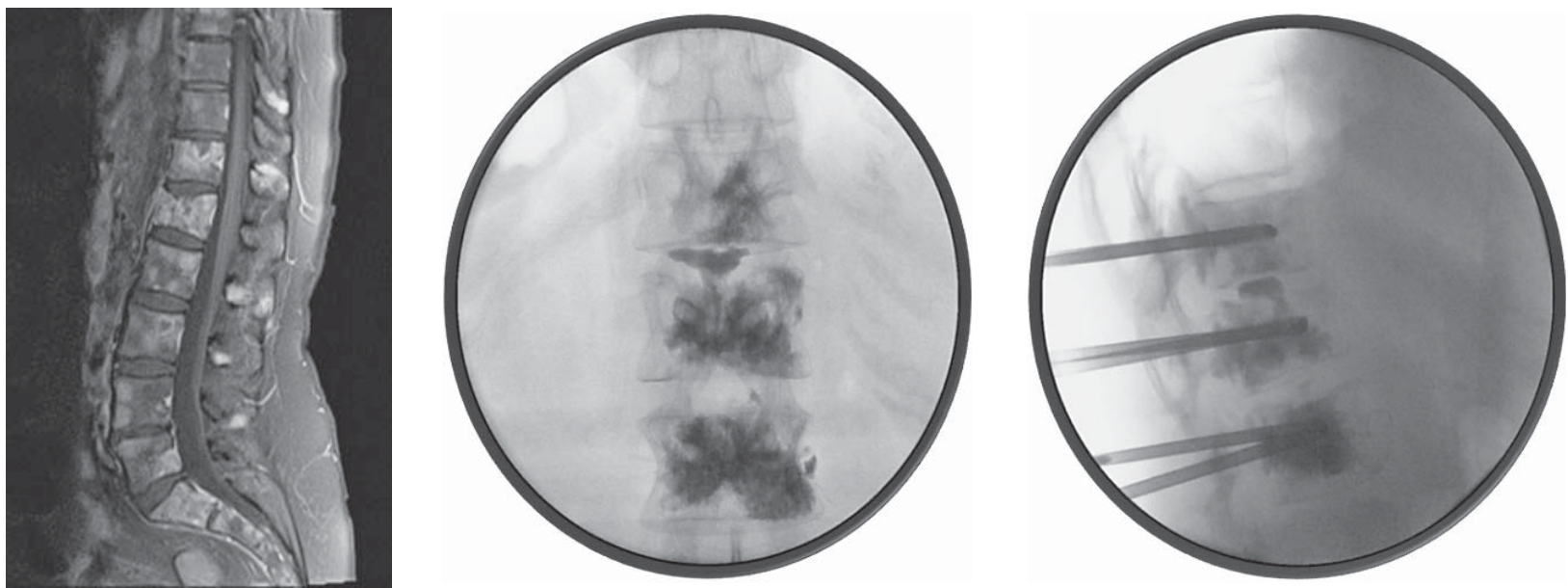

Fig. 5. Magnetic resonance image of multilevel metastatic involvement of the spinal column with corresponding intraoperative fluoroscopic images of percutaneous vertebral body augmentation (vertebroplasty) in the same patient.
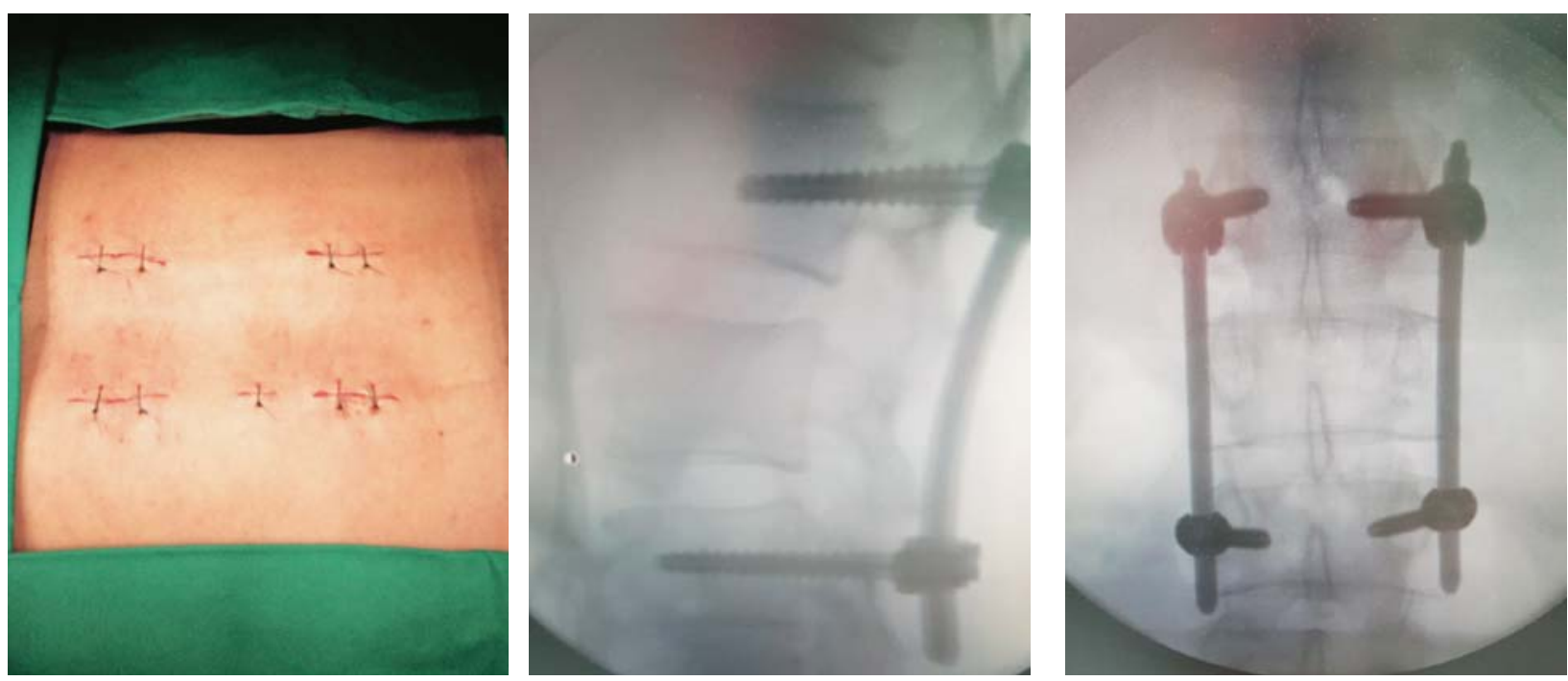

Fig. 6. Postoperative view of the skin incisions after minimally invasive (percutaneous) fixation of the lumbar spine with corresponding intraoperative fluoroscopic sagittal and coronal views. 

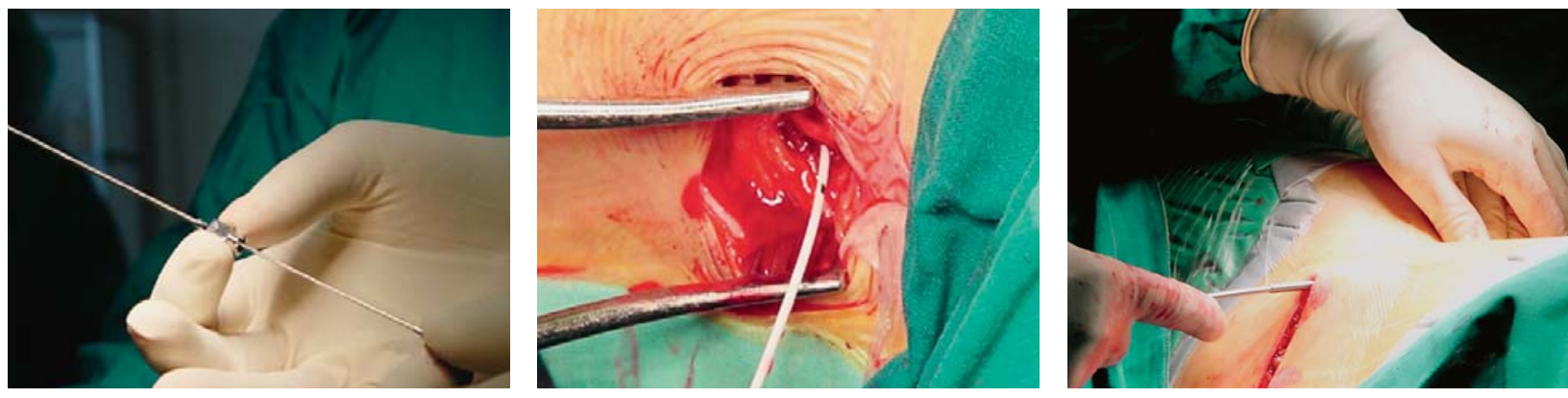

Fig. 7. Placement of an intrathecal pump device for administration of opioids.

\section{Conclusion}

Patients with spine metastases frequently present with complex diagnostic and therapeutic challenges requiring an integrated multi-step approach and multidisciplinary care, including a team of surgeons and oncologists. In managing these patients, every effort should be made to provide an early diagnosis and appropriate treatment for preservation of neurological function and quality of remaining life. Unfortunately, diagnosis is frequently not established until significant neurological deficit is present, by which time functional recovery may be unlikely. Newer surgical techniques that address decompression, spinal stabilization, with or without tumor resection, and minimally invasive pain relieving strategies must be taken into consideration in surgical candidates. Studies have shown clear benefit of surgical management in terms of maintaining ambulation and sphincter control, as well as in providing pain relief and prolonging patient independence. Although surgical intervention will not decrease mortality, it should nonetheless be strongly considered in patients that fulfill the established criteria for a reasonable outcome.

\section{References}

1. Lee CS, Jung CH. Metastatic spinal tumor. Asian Spine J. 2012 Mar;6(1):71-87. doi: 10.4184/asj.2012.6.1.71

2. Henschke N, Maher CG, Ostelo RW, De Vet HC, Macaskill P, Irwig L. Red flags to screen for malignancy in patients with low-back pain. Cochrane Database Syst Rev. [Research Support, Non-U.S. Gov't Review]. 2013(2):CD008686. doi: 10.1002/14651858.CD008686.pub2

3. Khmelevsky EV, Bychkova NM. [Radiosensitivity of bone metastases from tumors in different primary sites]. Vopr Onkol. [Randomized Controlled Trial]. 2015;61(1):77-84.
4. Wise JJ, Fischgrund JS, Herkowitz HN, Montgomery D, Kurz LT. Complication, survival rates, and risk factors of surgery for metastatic disease of the spine. Spine (Phila Pa 1976). 1999 Sep 15;24(18):1943-51.

5. Bašić Kes V, Bašić-Jukić N, Kes P, Demarin V, Labar B. [Neurologic sequelae of bone changes in multiple myeloma and its therapy]. Acta Med Croatica. [Review]. 2002;56(3):103-7. (in Croatian)

6. Harrington KD. Metastatic disease of the spine. J Bone Joint Surg Am. 1986 Sep;68(7):1110-5.

7. Harrington KD. Anterior decompression and stabilization of the spine as a treatment for vertebral collapse and spinal cord compression from metastatic malignancy. Clin Orthop Relat Res. $1988 \operatorname{Aug}(233): 177-97$.

8. Boriani S, Weinstein JN, Biagini R. Primary bone tumors of the spine. Terminology and surgical staging. Spine (Phila Pa 1976). [Research Support, Non-U.S. Govıt Review]. 1997 May 1;22(9):1036-44.

9. Tokuhashi Y, Matsuzaki H, Oda H, Oshima M, Ryu J. A revised scoring system for preoperative evaluation of metastatic spine tumor prognosis. Spine (Phila Pa 1976). [Comparative Study Evaluation Studies]. 2005 Oct 1;30(19):2186-91.

10. Quraishi NA, Manoharan SR, Arealis G, Khurana A, Elsayed $\mathrm{S}$, Edwards KL, et al. Accuracy of the revised Tokuhashi score in predicting survival in patients with metastatic spinal cord compression (MSCC). Eur Spine J. 2013 Mar;22 Suppl 1:S216. doi: 10.1007/s00586-012-2649-5

11. Leithner A, Radl R, Gruber G, Hochegger M, Leithner K, Welkerling $\mathrm{H}$, et al. Predictive value of seven preoperative prognostic scoring systems for spinal metastases. Eur Spine J. 2008 Nov;17(11):1488-95. doi: 10.1007/s00586-008-0763-1

12. Tomita K, Kawahara N, Baba H, Tsuchiya H, Nagata S, Toribatake Y. Total en bloc spondylectomy for solitary spinal metastases. Int Orthop. 1994 Oct;18(5):291-8.

13. Tomita K, Kawahara N, Kobayashi T, Yoshida A, Murakami H, Akamaru T. Surgical strategy for spinal metastases. Spine ( $\mathrm{Ph}-$ ila Pa 1976). [Case Reports]. 2001 Feb 1;26(3):298-306.

14. Patchell RA, Tibbs PA, Regine WF, Payne R, Saris S, Kryscio RJ, et al. Direct decompressive surgical resection in the 
treatment of spinal cord compression caused by metastatic cancer: a randomised trial. Lancet. [Clinical Trial Multicenter Study Randomized Controlled Trial Research Support, N.I.H., Extramural Research Support, U.S. Gov't, P.H.S.]. 2005 Aug 20-26;366(9486):643-8. doi: 10.1016/S0140-6736 (05)66954-1

15. Bilsky MH, Laufer I, Fourney DR, Groff M, Schmidt MH, Varga PP, et al. Reliability analysis of the epidural spinal cord compression scale. J Neurosurg Spine. [Research Support, Non-U.S. Gov't Validation Studies]. 2010 Sep;13(3):324-8. doi: 10.3171/2010.3.SPINE09459

16. Fisher CG, Dipaola CP, Ryken TC, Bilsky MH, Shaffrey CI, Berven $\mathrm{SH}$, et al. A novel classification system for spinal instability in neoplastic disease: an evidence-based approach and expert consensus from the Spine Oncology Study Group. Spine (Phila Pa 1976). [Case Reports Review]. 2010 Oct 15;35(22):E1221-9. doi: 10.1097/BRS.0b013e3181e16ae2

17. Laufer I, Rubin DG, Lis E, Cox BW, Stubblefield MD, Yamada Y, et al. The NOMS framework: approach to the treatment of spinal metastatic tumors. Oncologist. 2013 Jun; 18(6):744-51. doi: 10.1634/theoncologist.2012-0293
18. Kaloostian PE, Zadnik PL, Etame AB, Vrionis FD, Gokaslan ZL, Sciubba DM. Surgical management of primary and metastatic spinal tumors. Cancer Control. [Research Support, NonU.S. Gov't Review]. 2014 Apr;21(2):133-9.

19. Moulding HD, Elder JB, Lis E, Lovelock DM, Zhang Z, Yamada $Y$, et al. Local disease control after decompressive surgery and adjuvant high-dose single-fraction radiosurgery for spine metastases. J Neurosurg Spine. 2010 Jul;13(1):87-93. doi: 10.3171/2010.3.SPINE09639

20. Salapura V, Jeromel M. Minimally invasive (percutaneous) treatment of metastatic spinal and extraspinal disease - a review. Acta Clin Croat. [Review]. 2014 Mar;53(1):44-54.

21. Fourney DR, Schomer DF, Nader R, Chlan-Fourney J, Suki D, Ahrar K, et al. Percutaneous vertebroplasty and kyphoplasty for painful vertebral body fractures in cancer patients. J Neurosurg. 2003 Jan;98(1 Suppl):21-30.

22. Mendel E, Bourekas E, Gerszten P, Golan JD. Percutaneous techniques in the treatment of spine tumors: what are the diagnostic and therapeutic indications and outcomes? Spine (Phila Pa 1976). [Review]. 2009 Oct 15;34(22 Suppl):S93-100. doi: 10.1097/BRS.0b013e3181b77895

Sažetak

\section{KIRURŠKO LIJEČENJE METASTAZA KRALJEŽNICE}

\section{Franić, V. Bilić, S. Dokuzović, S. Ćurić, T. Čengić i K. Rotim}

Metastatska bolest kralježnice je dosta učestala i zasigurno zaslužuje pozornost i liječenje zbog visoke vjerojatnosti da bi inače bolesnici s karcinomom ostali oduzeti u svojim posljednjim mjesecima života. Novija postignuća i shvaćanja ponašanja raznih tipova tumora te unaprjeđenja u kirurškim tehnikama omogućuju evoluciju algoritama, pogotovo kada se kirurško liječenje razmatra. Ovaj rad daje pregled postupka donošenja odluka i ističe razne kirurške mogućnosti koje su trenutno dostupne.

Ključne riječi: Kralježnica - kirurgija; Kralježnica - patologija; Kralježnica, tumori, sekundarni; Metastaze - kirurgija; Palijativna skrb-metode; Algoritmi; Odlucivanje, tebnike potpore 